\title{
Exchange Traded Funds: Co-Integration and the U-Shape
}

\author{
Samique March-Dallas \\ Florida A\&M University
}

Robert Daigler
Florida International University
Suchi Mishra
Florida International University

Arun Prakash

Florida International University

This paper analyzes the intraday shape of New York Stock Exchange (NYSE) ETFs as well as iShares ETFs cross-traded on both the NYSE and London Stock Exchange (LSE). We found the intraday U-shape pattern for NYSE ETFS and NYSE iShares ETFs for trade price volatility, volume, and depth. However, the LSE iShares ETFS have a shape that is consistent with a double humped pattern. The US and the UK markets are not integrated across the whole day but in the overlapping period there is evidence of integration with limited price discovery outside of the financial meltdown of 2008.

Keywords: Exchange Traded Funds, Co-integration, U-shape

\section{INTRODUCTION}

The efficient market hypothesis (Fama, 1970) has been a stalwart issue in financial literature for several decades. However, if efficient markets were to truly exist, then arbitrage opportunities would not concurrently exist. Furthermore, there would be no evidence of a lagged relationship between markets, which provides arbitrage opportunities to traders. Trading in different markets that have non-overlapping or a few hours of overlapping trading hours should not result in available arbitrage opportunities, provided that markets are integrated. However, some markets seem to lag behind others and are affected by new revelations from other markets (Werner \& Kleidon, 1996; Hupperets \& Menkveld, 2002; Lin, Engle, \& Ito, 1994).

Therefore, if there is such a lag, or if it takes a significant time interval between trades for prices to coincide when one market opens and another closes, then this time lag would be an instrumental consideration when modeling price movements and evolution. This relationship can best be analyzed by looking at their intraday characteristics and how long it takes for markets to get integrated. This paper analyzes the intraday shape of volatility, volume, and depth for ETFs on the domestic New York Stock 
Exchange (NYSE) as well as for iShares ETFs traded on both the NYSE and London Stock Exchange (LSE). The intraday shape for the iShares ETFs grants insight into the market integration of both markets, where market integration is defined as the reflection of the same intrinsic information in prices in both markets.

There has been an observed U-shape in US market equities (Goodhart \& O'hara, 1997; Jain \& Joh, 1988; McInnish \& Wood, 1992) as well as evidence of the U-shape in the London market (Werner \& Kleidon, 1996; Abhyankar, Ghosh, Levin, \& Limmack, 1997). Therefore, this backdrop provides good material to examine market integration relationships since in integrated trading there should be one distinct U-shape instead of two. However, we will be using exchange traded funds (ETFs) to observe the market co-integration. Since the ETFs' intraday characteristics have not been documented, we must first ascertain the intraday shape of the volume, volatility, and spread for the ETFs in order to proceed. Studying these basket securities provides us with an insight into the intraday shape of reduced risk securities, where unsystematic risk has been reduced compared to each individual stock in the underlying portfolio. Previous literature has used individual equities to look at the intraday shape and not basket securities.

Since risk is often represented by volatility, does the reduction of risk through diversification play a significant role in the intraday shape of reduced risk securities even though we still observe the U-shape documented for individual stocks? The characteristics of the intraday shape of ETFs in the NYSE are first examined individually. The intraday characteristics of the universe of iShares ETFs in both New York and London are first compared, then the iShares ETFs that are based on the same underlying and traded in both New York and London are compared to see if there is an integrated U-shape or whether there are two distinct U-shapes as previously observed (Hupperets \& Menkveld, 2002; Werner \& Kleidon, 1996). Does the location of trade matter, where trading on one exchange is superior to trading another? Does sequential trading of cross-listed ETFs produce an integrated U-shaped intraday pattern? Does the US macro-economic news affect London more than London's news affects the US as shown in Hupperets and Menkveld (2002) as well as in Lin, Engle, and Ito (1991)?

If markets were perfectly co-integrated, then the shape should transfer from one market to another uniformly. However, if any of the intraday shapes should deviate, particularly between the close of the LSE and the opening of the NYSE, then the markets would suffer from a time lag in integration. If there is such a deviation, is it present every day or is it just a fluke that appears in a random fashion? There has been little work done on the intraday shape of exchange traded funds or the co-integration effects between markets of reduced risk basket securities, such as ETFs. This study differs from Werner and Kleidon (1996) since some of the stocks used in their study are traded as ADRs, which have to be converted to observe true arbitrage, and that is not the case with the ETFs. As a result, ETFs do not have the cost of conversion that ADRs have, and neither do they have the same risk level due to the inherent diversification of a fund. Therefore, this paper fills a void in the literature.

The remainder of the paper is divided into sections as follows: literature review and hypothesis, data and methodology, results, and conclusion.

\section{LITERATURE REVIEW AND HYPOTHESIS}

The characteristics of intraday data have piqued the interest of many as they provide a view into price evolution. These characteristics - namely that of volatility, volume, and depth - help to illustrate how prices behave and evolve over time. Analyzing and comparing these characteristics across markets help us to understand how markets relate and react to each other. Hupperets and Menkveld (2002) found that there is a U-shaped difference when looking at cross-listed stocks in Amsterdam and New York, so these two markets are not perfectly integrated. Froot and Dabora (1999), as well as Werner and Kleidon (1996), found evidence that financial markets are not one hundred percent integrated. Lin, Engle, and Ito (1994) found that while markets are not integrated, the US movement affects other markets, but this effect is asymmetric as it does not occur the other way around. The level of market integration is of utmost importance as we live in an ever changing and globalized world. 
Before analysis, the market structure of the markets paired for comparative purposes need to have some underlying thread that could explain why these markets would be integrated. In the case of London and New York, both of these exchanges are open trading environments with virtually complete access for foreign investors. There are no regulatory constraints to prevent cross-border arbitrage in dual listed stocks, and the markets are heavily arbitraged by institutional investors. In particular, the LSE has a higher amount of institutional investors (Cai, Hudson, \& Keasey, 2004). Dual listed stocks are liquid in both London and New York trading. Dealers in dual listed stocks potentially face considerable crossAtlantic competition for order flow. London stocks trade on the LSE SETS system, which was introduced in 1997. The trading day typically runs from 8:00 a.m. to 4:30 p.m. London time. However, there is no rigid starting and ending time as trading can begin anytime between 8 a.m. and 8:30 a.m. and end anytime between 4 p.m. and 4:30 p.m. This time frame translates to 3:00 a.m. to 11:30 a.m., New York time. The NYSE operates from 9:30 a.m. to 4:00 p.m., New York time. There is a two-hour overlap - 9:30 a.m. to 11:30 a.m., New York time - in the trading times for these two exchanges. This overlap allows for testing of the impact of macro-economic news and the effects of contagion. In Werner and Kleidon (1996), London was not affected by the news from the US, but in a more vertically integrated globalised world, the news effect in cross-border relationships ought to be significant as shown in Hupperets and Menkveld (2002) as well as in Lin, Engle, and Ito (1991).

Another aspect that has to be taken into account is the frequency of the data. Previously, much research used to be done with low frequency data, such as monthly and weekly data. However, much information is left out when using low frequency data as opposed to intraday data (Goodhart \& O'hara, 1997). Since financial markets operate, during their opening hours, on a continuous, high frequency basis, then it makes perfect sense that studies done on these markets should utilize as high as possible frequency data. It is, therefore, only by looking at the highest frequency continuous time series that one could observe temporal interrelationships between markets connected by such (arbitrage) interrelationships. The intraday pattern is also important to know for traders in these markets. This pattern helps to guide traders when it comes to correct timing to place trades, as well as the modeling of price movements, in financial markets.

Issue one looks at the characteristics of reduced risk basket securities, which trade on the domestic NYSE market, by examining ETFs. Diversification reduces risk in a basket of securities so that their shape exhibits less volatility than the individual assets that make up their portfolios. Therefore, this risk reduction may also be exhibited in the observed intraday pattern, and a deviation from the U-shape may occur. This issue is analyzed by considering the subsequent question: How much different from stocks is the intraday shape of ETFs when characterizing volatility, volume, and depth? I hypothesize that the intraday shapes of volume, volatility, and depth of ETFs differ from that of stocks, due to the diversification benefits inherent in ETFs.

Issue two looks at the intraday characteristics of iShares ETFs that are listed on both the NYSE and the LSE. If these two were perfectly co-integrated, then they would exhibit a stylized shape like the one shown in FIGURE 1. This issue is analyzed by considering the questions: Does location of trade matter? Is one market more liquid or volatile than the other? Are markets integrated for the overlapping trading period based on their shape? If there is a time lag in integration, is it persistent every day, or does it appear randomly? How much does US macroeconomic news affect ETF prices in London and vice versa? This series of questions leads to the following hypotheses: I hypothesize that markets are not integrated over the whole day but show integration in their overlapping period, so location of trade does matter. In addition, the lag in integration does not appear randomly, but it is present every day in the same interval of time. Furthermore, there is a more powerful effect of economic news from the New York to London but not vice versa.

\section{DATA AND METHODOLOGY}

ETFs would provide a good database for studying integration because they are basket securities and through diversification have eliminated much of the individual stock risk. Therefore, any lapse in 
integration would represent market specific factors and not those of individual stocks. The two markets to be looked at are the London Stock Exchange (LSE) and the New York Stock Exchange (NYSE) for nine months of data: September to November 2008 and June to November 2010. These two markets provide much ETF volume and are a good fit for a study on ETFs. The iShares group of ETFs is touted as having the most ETFs under management. There are over 300 iShares ETFs being traded in the US while there are over 250 being traded in London. Thus, there is a good number of ETFs to conduct the research. Of that number, 37 are dual listed ETFs.

ETFs' intraday data for the US were readily available on TAQ. TAQ provided the bids, asks, and trades of the US ETFs. ETFs' intraday data for London were available from the LSE. The CRSP data files were accessed through WRDS to get an accounting of all the US ETFs that were being traded. This list was cross referenced with the TAQ database in order to filter out ETFs from the universe of daily traded equities. Additionally, the Bloomberg terminal was used to get a list of all iShares ETFs that were traded on the LSE and the NYSE. These two lists were merged based on the underlying ETF to result in a list depicting iShares ETFs that were traded both in London and in New York (dual listing). Concentrating on the intraday activity required excluding any overnight positions. Therefore, all observations before the opening of the market - 9:30 a.m. in New York and 8:00 a.m. in London - and after the closing of the market at 4:00 p.m. in New York and at 4:30 p.m. in London were removed. If the price or volume was equal to zero or negative, then the trade was deleted. The data were separated into 15-minute intervals for the analysis. The first interval for the New York data was 9:30:01 to 9:44:59 while for the British data, it was 8:00:01 to 8:14:59. This time frame resulted in 36, 15-minute intervals for the LSE data and 27 for the NYSE data.

Integration is assessed both directly and indirectly - indirectly through the study of intraday patterns, which builds on Werner and Kleidon (1996), and directly by modeling price discovery during the two overlapping trading hours. For separate markets to be viewed as an integrated one, there should be a fusing of their U-shaped pattern instead of two distinct U-shapes for each market, so this approach provides a way to indirectly test for integration (see FIGURE 1). If markets are not integrated on a wholeday basis, as evidenced by a fused U-shape, are they integrated for the two-hour overlapping period? If both price series are co-integrated, then this finding would be a direct modeling of price discovery.

The trading variables explored are trade price volatility, volume, and depth. The interval return is calculated as log difference between the trade price prevailing at the start of the interval as is inferred from the last trade and the prevailing price at the end of the interval. The total number of shares traded in each interval is summed up to give the interval trading volume. The number of trades in each trading interval is the depth of trades. Intraday patterns for volatility, volume, and depth are estimated using ordinary least squares regression. The trading variables for each specific day and minute intervals are scaled by the daily mean. Similar to Werner and Kleidon (1996), these scaled variables are used in a cross-sectional regression in order to arrive at the intraday patterns.

$\begin{aligned} \frac{Y_{f, d, t}}{\delta_{f, t}}= & \sum_{i=t_{0}}^{T} J^{i}(t) \alpha_{i}+\left(\sum_{i=t_{0}}^{T}\left(J^{i}(t) \sigma_{i}\right)\right) \varepsilon_{f, d, t} \\ & \text { Y - either volume, volatility or spread, } \\ & \mathrm{f}-\text { ETF } \\ & \mathrm{d}-\text { day } \\ & \mathrm{t} \text { - time interval } \\ & \delta \text { - represents the fund specific, day specific mean }\end{aligned}$

$\mathrm{J}^{\mathrm{i}}(\mathrm{t})-\{0,1\}$ dummy vector with value of 1 only when $\mathrm{i}=\mathrm{t}$

$\varepsilon_{\mathrm{f}, \mathrm{d}, \mathrm{t}}$ - iid error term $\left(\mu=0, \sigma^{2}=1\right)\left[\sigma^{2}\right.$ - intraday variance and can be heteroskedastic].

Price differences should be transient for arbitrage reasons and, therefore, stationary. The null hypothesis of market integration for price discovery during the overlap is tested by evaluating whether or not both price series are co-integrated. The Dickey-Fuller Test is used to test for market integration. If 
there is high volume and high volatility, there are typically large spreads and integrated price discovery. This dynamic suggests that we can discover a causal relationship. The vector error correction model proposed by Hasbrouck (1995) is a valuable tool to help determine from where this relationship originates.

FIGURE 1

THE STYLIZED U-SHAPE FOR INTEGRATED MARKETS

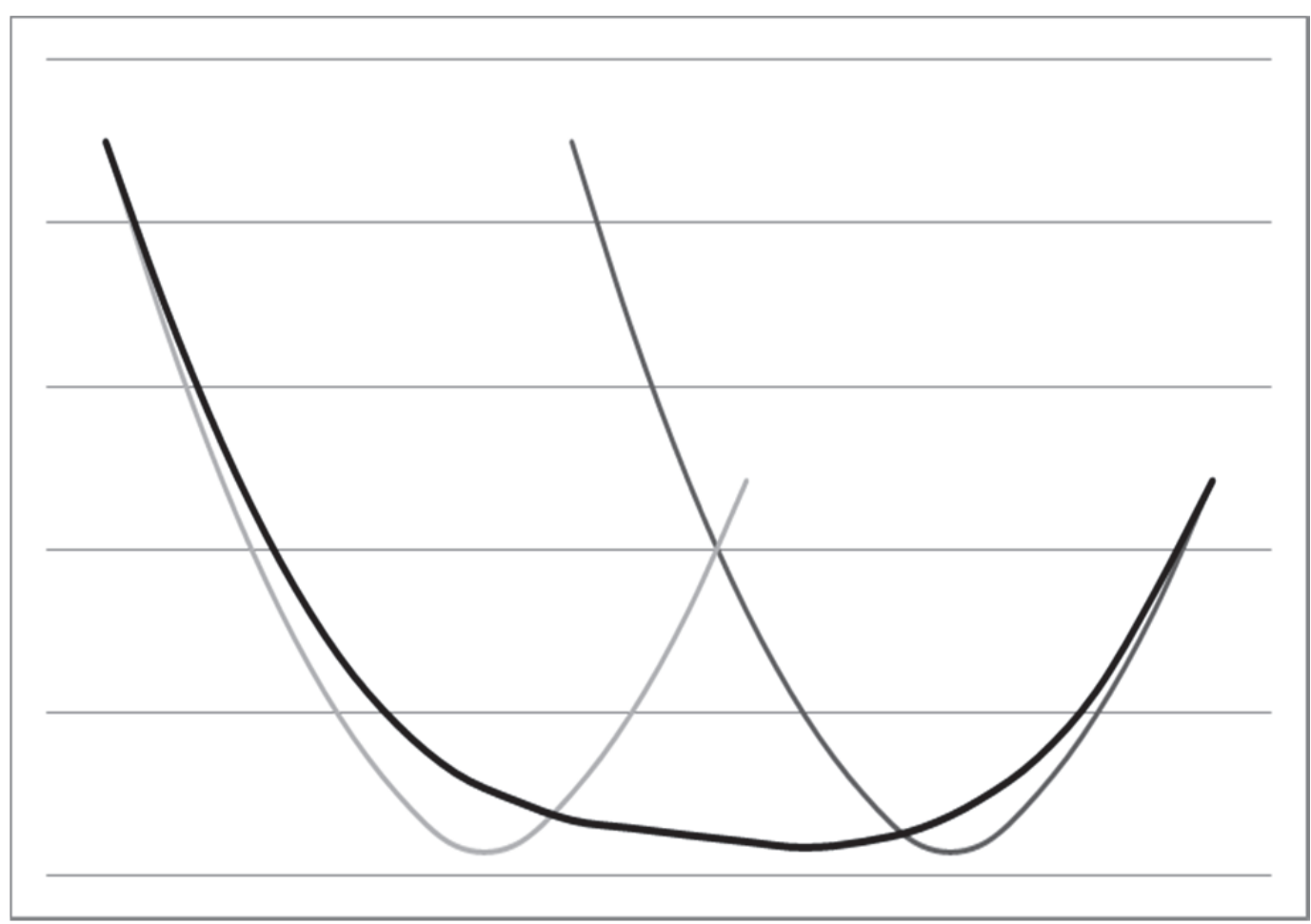

The thin lines represent the two individual markets while the thick line represents the hypothesized integrated markets. The model involves solving the following system of equations

$$
\begin{aligned}
r_{t}^{L}= & \Delta \log \left(P_{t}^{L}\right) \\
r_{t}^{N}= & \Delta \log \left(P_{t}^{N}\right) \\
r_{t}^{L}= & \alpha^{L}\left(\log \left(P_{t-1}^{L}\right)-\log \left(P_{t-1}^{N}\right)\right)+\sum_{i=1}^{4} \gamma_{i}^{L, L} r_{t-i}^{L}+\sum_{i=1}^{4} \gamma_{i}^{L, N} r_{t-i}^{N}+\varepsilon_{t}^{A} \\
r_{t}^{N}= & \alpha^{N}\left(\log \left(P_{t-1}^{L}\right)-\log \left(P_{t-1}^{N}\right)\right)+\sum_{i=1}^{4} \gamma_{i}^{N, L} r_{t-i}^{L}+\sum_{i=1}^{4} \gamma_{i}^{N, N} r_{t-i}^{N}+\varepsilon_{t}^{N} \\
& \mathrm{r}-\text { return } \\
& \mathrm{P}-\text { price } \\
& \mathrm{t}-\text { time } \\
& \mathrm{L} \text { - London } \\
& \mathrm{N} \text { - New York }
\end{aligned}
$$




\section{RESULTS}

After data collection, the data were summarized to get a general view. Summary statistics for both the 2008 and 2010 periods are reported in Table 1 for the entire day while Table 2 depicts the overlapping two-hour period between the NYSE and the LSE.

TABLE 1

SUMMARY STATISTICS OF ETFS

\begin{tabular}{|c|c|c|c|c|c|c|}
\hline & \multicolumn{3}{|c|}{2008} & \multicolumn{3}{|c|}{2010} \\
\hline & Volatility & Volume & Depth & Volatility & Volume & Depth \\
\hline \multicolumn{7}{|c|}{ Panel A: New York Trading (NY) } \\
\hline \multicolumn{7}{|c|}{ All ETFS } \\
\hline Mean & $5.14 \mathrm{e}-04$ & 87148 & 258.9 & $5.76 \mathrm{e}-04$ & 42519 & 115.1 \\
\hline Std Deviation & $1.13 \mathrm{e}-02$ & 525362 & 1035.5 & $2.61 \mathrm{e}-02$ & 216924 & 420.5 \\
\hline First Quartile & $1.73 e-06$ & 900 & 4 & 0 & 624 & 3 \\
\hline Median & $1.08 \mathrm{e}-05$ & 4140 & 14 & $1.11 \mathrm{e}-06$ & 3300 & 12 \\
\hline Third Quartile & $4.81 \mathrm{e}-05$ & 23413 & 100 & $5.02 \mathrm{e}-06$ & 18757 & 68 \\
\hline \#of ETFs & 768 & 768 & 768 & 675 & 675 & 675 \\
\hline \multicolumn{7}{|l|}{ All iShares ETFS } \\
\hline Mean & $4.21 \mathrm{e}-05$ & 75108 & 264.2 & $3.15 \mathrm{e}-06$ & 35085 & 99.2 \\
\hline Std Deviation & $2.65 \mathrm{e}-04$ & 635742 & 982.7 & $9.52 \mathrm{e}-06$ & 142654 & 319.1 \\
\hline First Quartile & $1.16 \mathrm{e}-06$ & 1300 & 6 & $9.95 \mathrm{e}-08$ & 837 & 4 \\
\hline Median & $7.46 \mathrm{e}-06$ & 6300 & 26 & $6.58 \mathrm{e}-07$ & 3500 & 15 \\
\hline Third Quartile & $3.12 \mathrm{e}-05$ & 27400 & 131 & $2.77 \mathrm{e}-06$ & 14749 & 55 \\
\hline \# of ETFs & 174 & 174 & 174 & 175 & 175 & 175 \\
\hline \multicolumn{7}{|l|}{ Dual-listed iShares ETFS } \\
\hline Mean & $3.64 \mathrm{e}-05$ & 312714 & 842.7 & $2.19 \mathrm{e}-06$ & 127310 & 239.1 \\
\hline Std Deviation & $1.47 \mathrm{e}-04$ & 886648 & 2268 & $5.83 e-06$ & 330086 & 87.7 \\
\hline First Quartile & $1.08 \mathrm{e}-06$ & 7274 & 33 & $5.42 \mathrm{e}-08$ & 394 & 13 \\
\hline Median & $6.85 \mathrm{e}-06$ & 32100 & 113 & $3.89 \mathrm{e}-07$ & 17632 & 52 \\
\hline Third Ouartile & $2.83 \mathrm{e}-05$ & 218846 & 473 & $1.81 \mathrm{e}-06$ & 92751 & 169 \\
\hline \# of ETFS & 31 & 31 & 31 & 31 & 31 & 31 \\
\hline \multicolumn{7}{|c|}{ Panel B: London Trading (LN) } \\
\hline $\begin{array}{l}\text { All iShares ETFS } \\
\text { Mean }\end{array}$ & $5.03 \mathrm{e}-04$ & 60528 & 5.23 & $9.06 \mathrm{e}-04$ & 25513 & 4.12 \\
\hline Std Deviation & $1.85 \mathrm{e}-02$ & 230918 & 10.31 & $8.27 \mathrm{e}-02$ & 155283 & 7.75 \\
\hline First Quartile & $2.14 \mathrm{e}-07$ & 556 & 1 & 0 & 280 & 1 \\
\hline Median & $4.12 \mathrm{e}-06$ & 3500 & 2 & $1.01 \mathrm{e}-06$ & 1373 & 2 \\
\hline Third Quartile & $2.55 \mathrm{e}-05$ & 21171 & 4 & $3.08 \mathrm{e}-06$ & 8598 & 4 \\
\hline \# of ETFS & 109 & 109 & 109 & 171 & 171 & 171 \\
\hline \multicolumn{7}{|l|}{ Dual-listed iShares ETFS } \\
\hline Mean & $3.66 e-04$ & 29253 & 3.02 & $1.27 \mathrm{e}-04$ & 15424 & 3.27 \\
\hline Std Deviation & $1.05 \mathrm{e}-02$ & 164917 & 3.07 & $7.91 \mathrm{e}-03$ & 115923 & 3.82 \\
\hline First Quartile & $4.26 \mathrm{e}-07$ & 395 & 1 & 0 & 250 & 1 \\
\hline Median & $4.33 e-06$ & 2675 & 2 & $5.01 \mathrm{e}-07$ & 1100 & 2 \\
\hline Third Quartile & $3.85 \mathrm{e}-05$ & 15034 & 4 & $2.51 \mathrm{e}-06$ & 6124 & 4 \\
\hline \# of ETFS & 28 & 28 & 28 & 42 & 42 & 42 \\
\hline \multicolumn{7}{|c|}{ Panel C: Student T-test of Means $(N Y-L N=0)$} \\
\hline All iShares ETFs & $-3.02 * * *$ & $6.96 * * *$ & $108.22 * * *$ & $-2.40 * * *$ & $12.60 * * *$ & $151.14 * * *$ \\
\hline Dual-listed iShares ETFs & $-2.31 * *$ & $37.44 * * *$ & $45.40 * * *$ & $-2.14 * *$ & $51.72 * * *$ & $66.70 * * *$ \\
\hline
\end{tabular}

The dates for analysis are September through November 2008 and June through November 2010. 
TABLE 2

SUMMARY STATISTICS IN THE TWO-HOUR OVERLAP PERIOD FOR ETFS

\begin{tabular}{|c|c|c|c|c|c|c|}
\hline & \multicolumn{3}{|c|}{2008} & \multicolumn{3}{|c|}{2010} \\
\hline & Volatility & Volume & Depth & Volatility & Volume & Depth \\
\hline \multicolumn{7}{|c|}{ Panel A: New York Trading (NY) } \\
\hline \multicolumn{7}{|c|}{ All ETFS } \\
\hline Mean & $1.16 \mathrm{e}-04$ & 93741 & 290.7 & $9.18 \mathrm{e}-06$ & 53877 & 160.31 \\
\hline Std Deviation & $4.91 \mathrm{e}-03$ & 486648 & 1127.8 & $2.91 \mathrm{e}-05$ & 206657 & 543.37 \\
\hline First Quartile & $2.03 \mathrm{e}-06$ & 1000 & 4 & $2.96 \mathrm{e}-07$ & 1000 & 4 \\
\hline Median & $1.41 \mathrm{e}-05$ & 4556 & 14 & $1.79 \mathrm{e}-06$ & 4800 & 17 \\
\hline Third Quartile & $5.73 e-05$ & 25601 & 104 & $7.30 \mathrm{e}-06$ & 26626 & 98 \\
\hline \multicolumn{7}{|l|}{ All iShares ETFS } \\
\hline Mean & $5.75 \mathrm{e}-05$ & 83276 & 290.2 & $4.99 \mathrm{e}-06$ & 45736 & 128.41 \\
\hline Std Deviation & $4.51 \mathrm{e}-04$ & 340324 & 1029.3 & $1.06 \mathrm{e}-05$ & 170585 & 393.66 \\
\hline First Quartile & $1.56 \mathrm{e}-06$ & 1473 & 6 & $1.96 \mathrm{e}-07$ & 1100 & 5 \\
\hline Median & $9.74 \mathrm{e}-06$ & 7110 & 26 & $1.28 \mathrm{e}-06$ & 4660 & 18 \\
\hline Third Quartile & $3.87 \mathrm{e}-05$ & 30645 & 137.8 & $5.05 \mathrm{e}-06$ & 19394 & 71 \\
\hline \multicolumn{7}{|l|}{ Dual-listed iShares ETFS } \\
\hline Mean & $4.49 \mathrm{e}-05$ & 356933 & 975 & $3.43 \mathrm{e}-06$ & 178631 & 338.73 \\
\hline Std Deviation & $2.12 \mathrm{e}-04$ & 830968.5 & 2412.2 & $7.52 \mathrm{e}-06$ & 395108 & 755.79 \\
\hline First Quartile & $1.56 \mathrm{e}-06$ & 9386 & 39 & $1.01 \mathrm{e}-07$ & 5048 & 17 \\
\hline Median & $8.94 \mathrm{e}-06$ & 43698 & 140 & $7.45 \mathrm{e}-07$ & 30500 & 86 \\
\hline Third Quartile & $3.53 \mathrm{e}-05$ & 270638 & 542.5 & $3.35 \mathrm{e}-06$ & 145388 & 240 \\
\hline \multicolumn{7}{|c|}{ Panel B: London Trading (LN) } \\
\hline \multicolumn{7}{|c|}{ All iShares ETFS } \\
\hline Mean & $1.23 \mathrm{e}-03$ & 67611 & 5.33 & $1.77 \mathrm{e}-03$ & 25933 & 4.61 \\
\hline Std Deviation & $3.18 \mathrm{e}-02$ & 238697 & 10.81 & $1.15 \mathrm{e}-01$ & 96235 & 9.53 \\
\hline First Quartile & $5.02 \mathrm{e}-07$ & 716 & 1 & 0 & 367.5 & 1 \\
\hline Median & $7.23 e-06$ & 4030 & 2 & $1.02 \mathrm{e}-06$ & 1903 & 2 \\
\hline Third Quartile & $5.09 \mathrm{e}-05$ & 22873 & 4 & $5.05 \mathrm{e}-06$ & 10000 & 4 \\
\hline \multicolumn{7}{|l|}{ Dual-listed iShares ETFS } \\
\hline Mean & $5.05 \mathrm{e}-04$ & 35587 & 3.44 & $3.04 \mathrm{e}-04$ & 18910 & 3.39 \\
\hline Std Deviation & $1.32 \mathrm{e}-02$ & 125073 & 3.81 & $1.35 \mathrm{e}-02$ & 67062 & 4.576 \\
\hline First Quartile & $1.21 \mathrm{e}-06$ & 558 & 1 & $1.22 \mathrm{e}-07$ & 392 & 1 \\
\hline Median & $7.91 \mathrm{e}-06$ & 4000 & 2 & $9.01 \mathrm{e}-07$ & 1931 & 2 \\
\hline Third Quartile & $5.89 \mathrm{e}-05$ & 25000 & 4 & $4.42 \mathrm{e}-06$ & 10000 & 4 \\
\hline \multicolumn{7}{|c|}{ Panel C: Student T-test of Means $(N Y-L N=0)$} \\
\hline All iShares ETFs & $-2.42 * * *$ & $4.09 * * *$ & $63.79 * * *$ & $-1.93 * *$ & $20.47 * * *$ & $91.11 * * *$ \\
\hline Dual-listed iShares ETFs & -1.51 & $25.84 * * *$ & $27.67 * * *$ & $-1.75^{*}$ & $37.04 * * *$ & $41.48 * * *$ \\
\hline
\end{tabular}

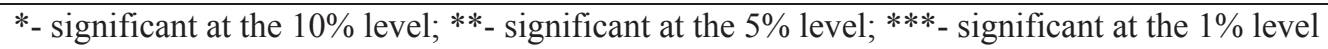

The dates for analysis are September through November 2008 and June through November 2010. Panel A of each table represents the trading in the New York market while Panel B represents the trading in the London market. Werner and Kleidon (1996) adjust for the impact of exchange rates on the trading variables. However, they find that stock prices and exchanges would need to be perfectly negatively correlated in order for the impact of exchange rates to skew the results. Since perfect negative correlation has not been observed between exchange rates and stock prices, I do not expect any change in results and I do not account for the impact of exchange rates. 
The New York panel provides a summary for three different groups: all ETFs (ETFs that are actively being traded, regardless of issuer), all iShares ETFs (ETFs that are actively traded and issued by iShares) and dual-listed iShares ETFs (ETFs that are issued by iShares and traded both in New York and London). The London panel provides a summary for two groups: all iShares ETFs and dual-listed iShares ETFs. Both markets are very liquid as observed by the average volume across all groups.

Table 1 illustrates that New York has more ETFs being traded, and that the NYSE has more volume and more depth than London. This circumstance may be due to the fact that ETFs started to be traded at an earlier date in New York than in London. This observation is consistent with the higher average volume per trade in New York that was observed by Werner and Kleidon (1996). Regardless of location, the average volume and average depth of trade was larger in 2008 than in 2010. In New York, the average trade price volatility was larger for the group, all ETFs, in 2010 versus 2008 . Conversely, the groups, all iShares ETFs and dual-listed iShares ETFs, had more trade price volatility in 2008 than in 2010. For London, the average trade price volatility for all iShares ETFs was larger in 2010 than in 2008, but the opposite was true for the dual-listed iShares ETFs. The amounts traded of these shares were larger in 2008 than in 2010. Therefore, it is reasonable to conclude that volatility is higher when volume is higher as more volume means more trading and more opportunities for the deviations of trade prices from the mean.

Table 2 shows similar results to Table 1. There is more volume and depth in the New York market than in the London market for ETFs in the two-hour overlapping period. There are also more volume and depth in both New York and London in 2008 compared to 2010 for the two-hour overlap. Also, trade price volatility is large in 2008 than in 2010 for all of the three groups for the New York market. Regarding trade price volatility in London, there is the same relationship in the two-hour overlap as in the whole day, where for the group, all iShares ETFs, there is a larger trade price volatility in 2010 compared to 2008. For the group, dual-listed iShares ETFs, trade price volatility in 2008 is larger than in 2010. It is interesting to note that in comparison to the whole trading day, the two-hour overlapping period in both 2008 and 2010 shows that both volume and depth increased across all groups regardless of location. Volatility varies slightly as the increase for the overlap compared to the whole day is shown for all groups except all ETFs in New York, where the volatility for the day as a whole is larger than the volatility in the two-hour overlap. This observation support the hypothesis that the two-hour overlapping period is distinguished from the entire day and creates an ideal time and place for arbitrageurs to trade.

Panel C of Tables 1 and 2 reports the t-statistics from the Welch's difference of means test - which tests the hypothesis that the means of trade price volatility, volume and, depth for New York and London are equal. A non-parametric test, the Wilcoxon rank sum test, was also conducted, and it verifies the results of the t-test, rejecting the null hypothesis in favor of the alternative where true location shift was not equal to 0 - hence it was not reported here. During the day as a whole, there is generally a statistically significant difference in both 2008 and 2010 for all three variables. Trade price volatility shows a negative significant difference while volume and depth show a positive significant difference in both 2008 and 2010. In other words, the volatility in the London market is typically larger than the volatility in New York, but volume and depth are larger in the New York market, which translates from Panel A. During the two hour-overlap, the variables have the same sign as during the whole day. While volume and depth retain a general positive statistical significance, volatility has a statistically significant difference for all iShares ETFs but not for the dual-listed iShares ETFs, where there is no significance in 2008 while there is a weak $10 \%$ significance level for 2010 .

The empirical intraday pattern for stocks in the US has been shown to reflect a U-shape. However, taking into consideration that ETFs are basket securities and thus benefit from reduced risk through diversification based on their construction, it is important to first construct the intraday patterns for all ETFs in the US to verify that they also follow the U-shaped intraday patterns recorded for US stocks. The intraday patterns for all ETFs traded on the New York market are first established by using the double pass regression from Werner and Kleidon (1996). This intraday pattern is shown in Figure 2 for both 2008 and 2010. All three variables show a distinct U-shaped pattern in 2008. There are more jumps seen for volatility resulting in a departure from the pure U-shape than for the other two variables. In 2010, 
while volume and depth show the conceived U-shape, volatility takes a dive in the last half hour of trading, and the U-shape becomes slightly distorted.

FIGURE 2

INTRADAY PATTERNS FOR ALL NEW YORK ETFS FOR 2008 AND 2010

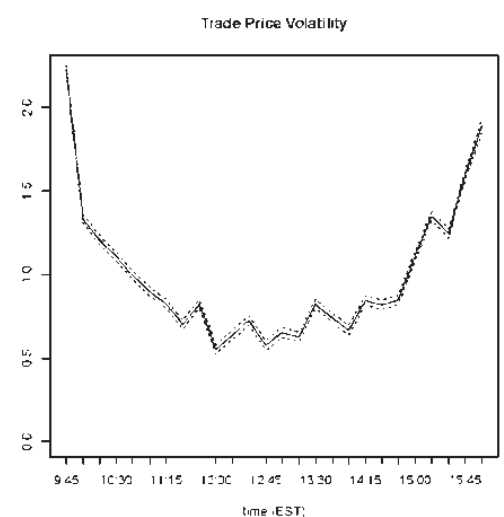

A

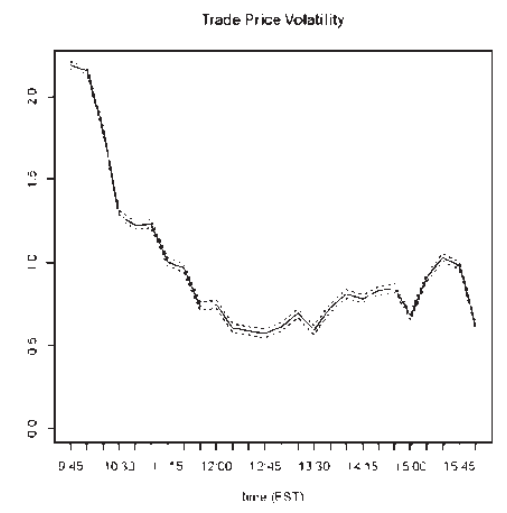

$\mathrm{D}$

The top panels, A, B, C, represent September through November 2008 while the bottom panels, D, E, F, represent June through November 2010. These graphs illustrate the results of the regression for the intraday patterns. The dotted line represents the $99 \%$ confidence interval.

Figures 3 and 4 show the intraday patterns for all iShares ETFs traded in New York and London, respectively. Figure 3 illustrates that the iShares ETFs follow a very similar intraday pattern to all the ETFs traded in the New York market, validating this group as a good choice as vehicle for this study. The pattern shows jumps in similar positions when compared to Figure 2, although some of these jumps are a tad sharper. The London iShares ETFs, on the other hand, in Figure 4 tell a very different story. This pattern resembles more of a sideways $\mathrm{J}$ shape for volatility and somewhat for volume and depth. The highest point seems to be at the end of the day, with oscillations occurring from when trade starts to when trade ends. This uptick in trading could be attributed to the opening of the markets in New York that occurs in the last two hours of trading in London. However, there are many jumps throughout the day to get to the uptick at the end of the day. With the knowledge that trading starts in London at 3:30 a.m. (New York time) then transitions to US trading at 9:30 a.m. (New York time), and then to close at 4:30 p.m. (New York time), these patterns show evidence of a non-integrated market as stylized by the disconnected markets in Figure 1. There is progression throughout the day from 3:30 a.m. (New York time) to 11:30 a.m. (New York time) in the London market, but at around 9:30 a.m. (New York time) - when the New 
York market opens - there is an uptick in the patterns. This uptick flows into the New York market from the time it opens to a decline in trading during the middle of the day, followed by an increase at the end of the day, to close out trading at 4:30 p.m. Therefore, it is immensely important to look at the occurrences during the overlapping two-hour period to see how these two markets transition.

FIGURE 3

INTRADAY PATTERNS FOR ALL NEW YORK ISHARES ETFS FOR 2008 AND 2010

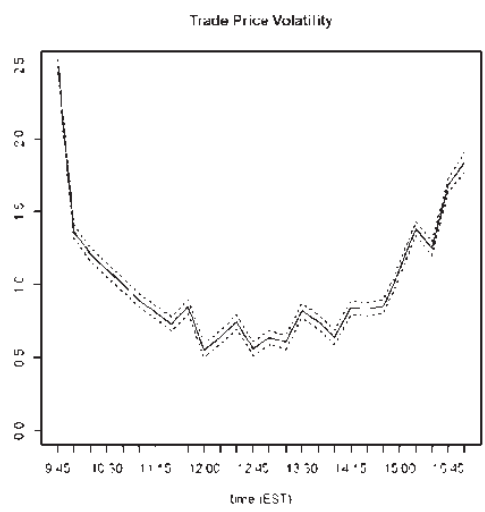

A

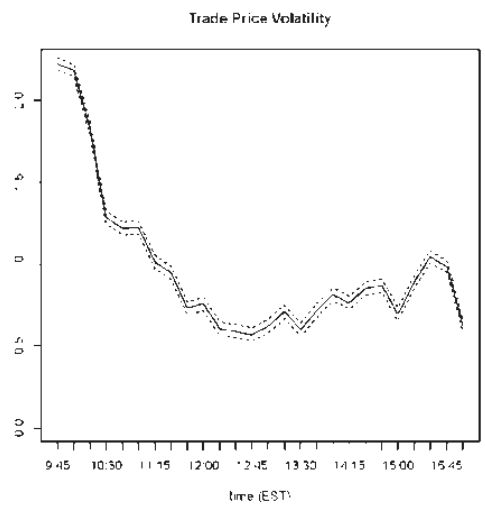

$\mathrm{D}$

The top panels, A, B, C, represent September through November 2008 while the bottom panels, D, E, F, represent June through November 2010. These graphs illustrate the results of the regression for the intraday patterns. The dotted line represents the $99 \%$ confidence interval.

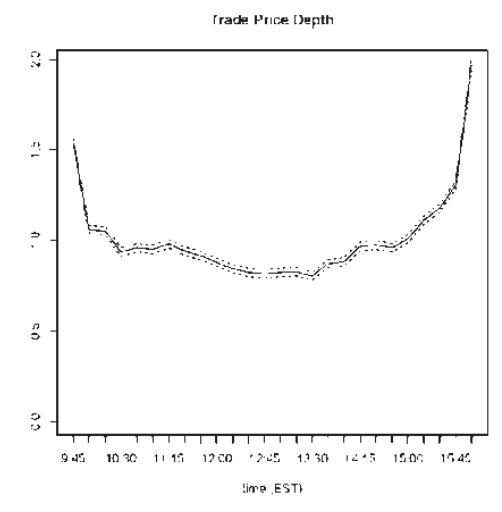

$\mathrm{C}$

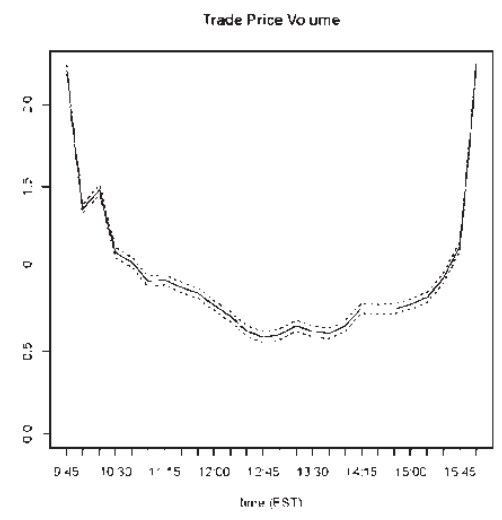

$\mathrm{E}$

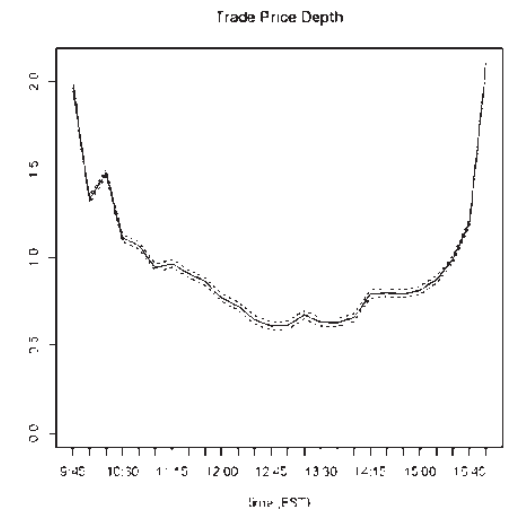

$\mathrm{F}$ 


\section{FIGURE 4}

\section{INTRADAY PATTERNS FOR ALL LONDON ISHARES ETFS FOR 2008 AND 2010}

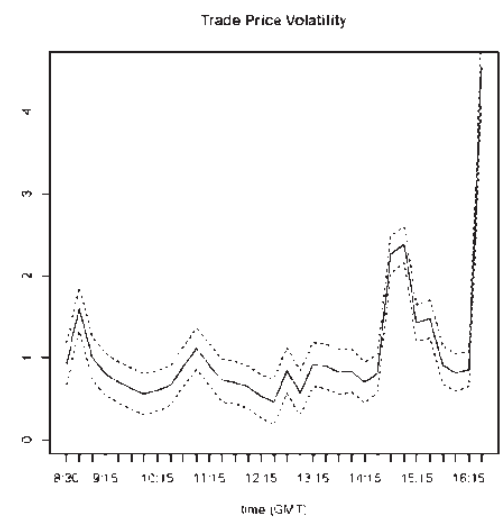

A

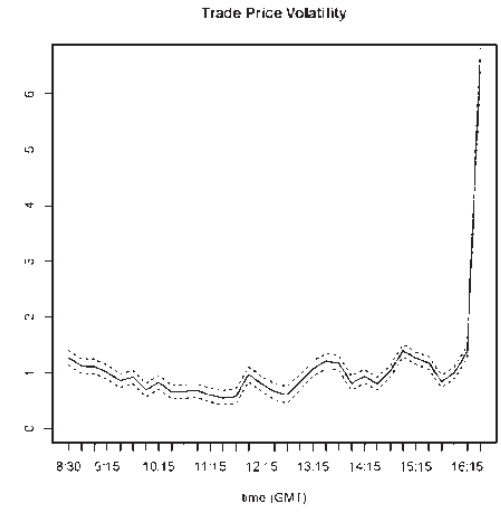

$\mathrm{D}$

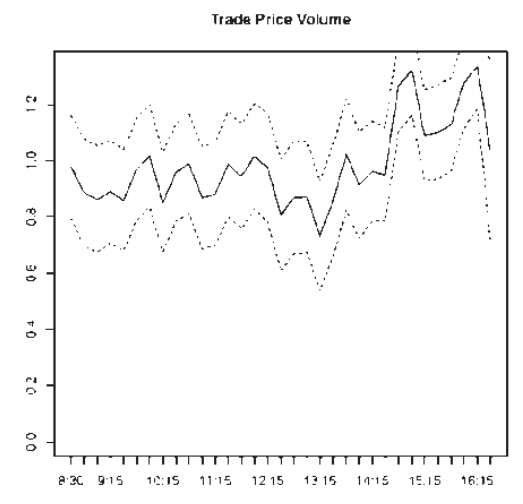

time isw

$\mathrm{B}$

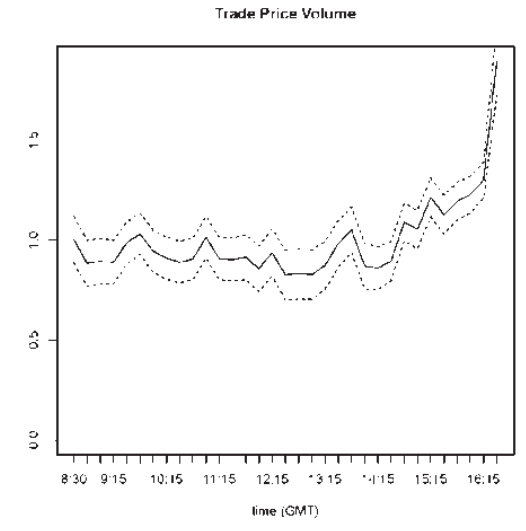

$\mathrm{E}$

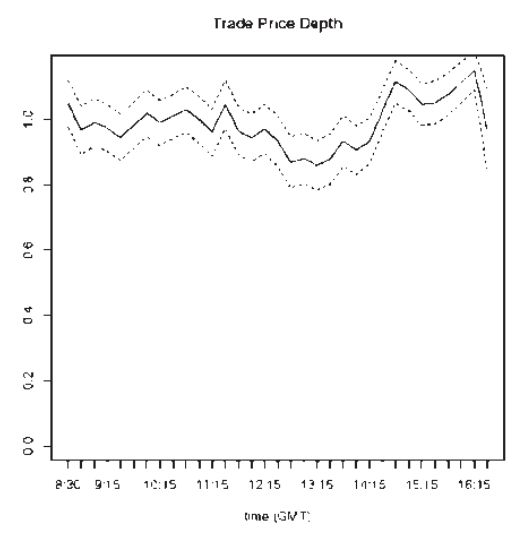

$\mathrm{C}$

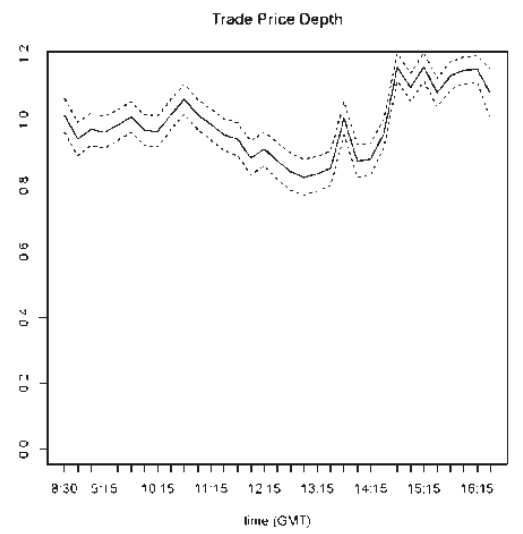

$\mathrm{F}$

The top panels, A, B, C, represent September through November 2008 while the bottom panels, D, E, F, represent June through November 2010. These graphs illustrate the results of the regression for the intraday patterns. The dotted line represents the $99 \%$ confidence interval.

Figures 5 and 6 report the pattern attributed to the dual-listed iShares ETFs that trade both in New York and London. The New York market shows an adherence to the established U-shaped pattern that was presented in Figure 2 with more pronounced deviations/jumps. It can still clearly be observed that there is an uptick at the beginning of trading which is larger than the trading in the middle of the day followed by another uptick at the end of the day. The London market shows a significant increase in the number of jumps throughout the day, especially in 2008. The pattern from Figure 6 showing 2008 depicts the contribution of increased panic in the worldwide markets through the distortion of the patterns. However, 2010 shows a reversion to what looks like the norm for the London market. 
FIGURE 5

INTRADAY PATTERNS FOR DUAL LISTED NEW YORK ISHARES ETFS

FOR 2008 AND 2010

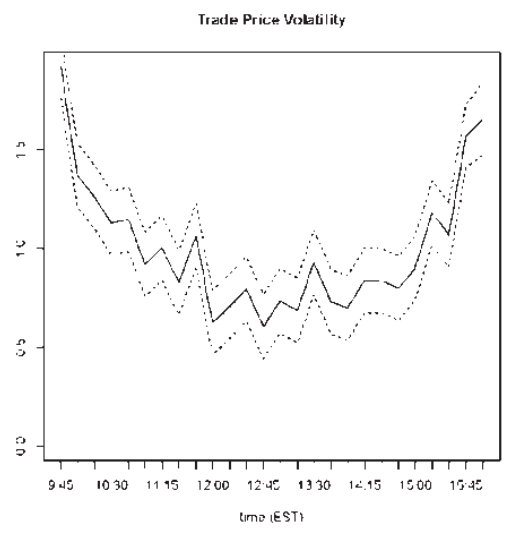

A

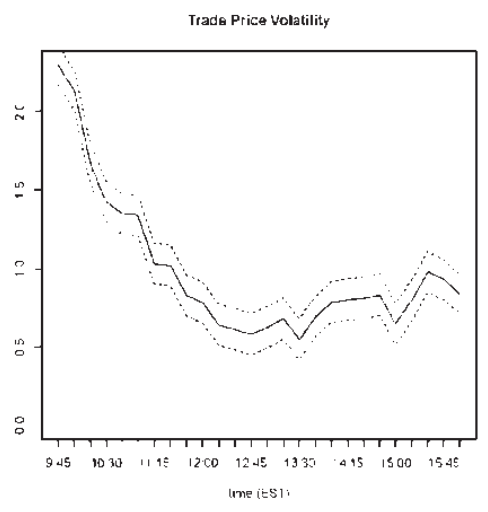

$\mathrm{D}$

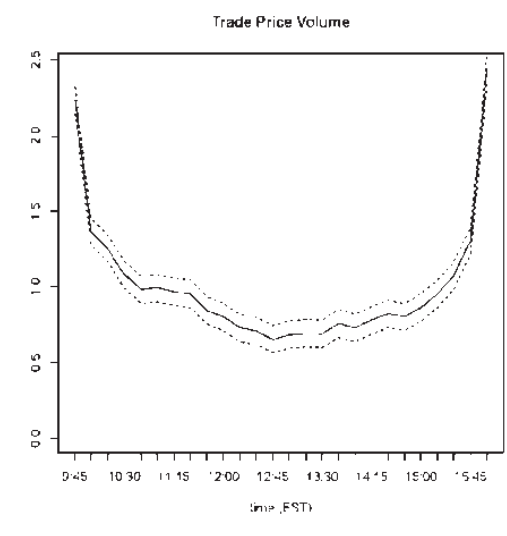

B

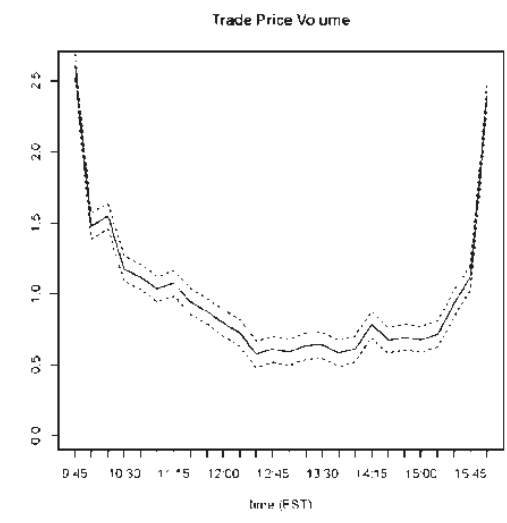

$\mathrm{E}$

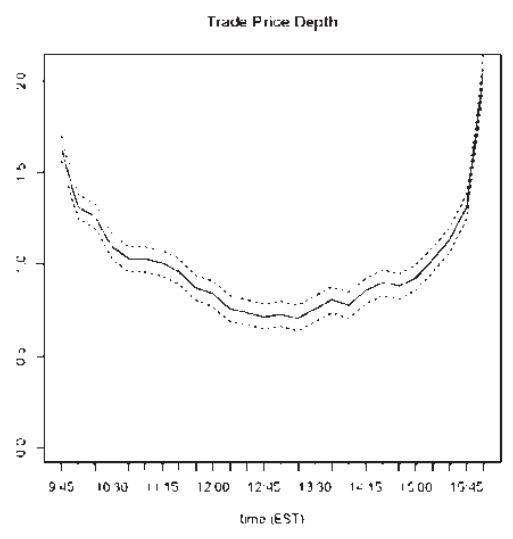

$\mathrm{C}$

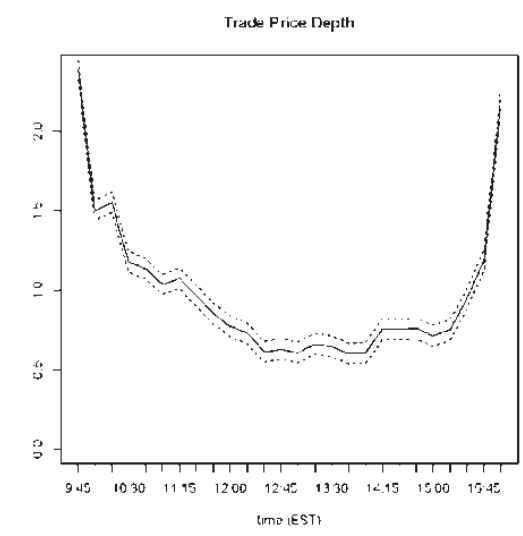

$\mathrm{F}$

The top panels, A, B, C, represent September through November 2008 while the bottom panels, D, E, F, represent June through November 2010. These graphs illustrate the results of the regression for the intraday patterns. The dotted line represents the $99 \%$ confidence interval. 
FIGURE 6

INTRADAY PATTERNS FOR DUAL LISTED LONDON ISHARES ETFS FOR 2008 AND 2010

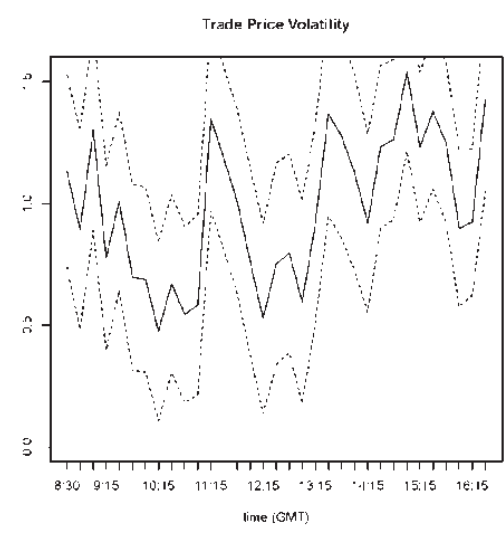

A

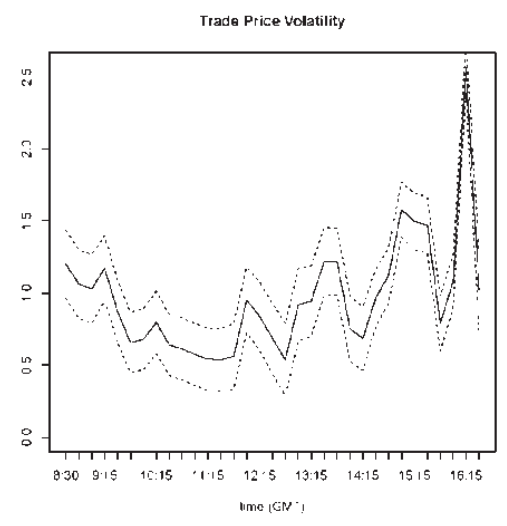

D

The top panels, A, B, C, represent September through November 2008 while the bottom panels, D, E, F, represent June through November 2010. These graphs illustrate the results of the regression for the intraday patterns. The dotted line represents the $99 \%$ confidence interval.

Figures 7 and 8 illustrate the pattern for the dual-listed ETFS that are traded in the overlapping twohour window between the New York and London markets. For the New York market, there is a clear decline from the beginning of the period to the end of the period for volatility, volume, and depth in both 2008 and 2010. For London in 2008, there is a general increase from the beginning of the period to the end of the period for volatility, volume, and depth. However, in 2010, volume and depth show a steady increase over the period while volatility reverts back to its starting point with several jumps between the beginning and the end of the period. In the London market, there appear to be quite a few jumps throughout the day and in the overlapping period. This dynamic renders it difficult to ascertain the cause of these jumps, thus measuring the impacts from US news and the opening of a new market in the overlap hours. 
FIGURE 7

INTRADAY PATTERNS FOR ALL DUAL-LISTED NEW YORK ISHARES ETFS IN THE OVERLAPPING PERIOD FOR 2008 AND 2010

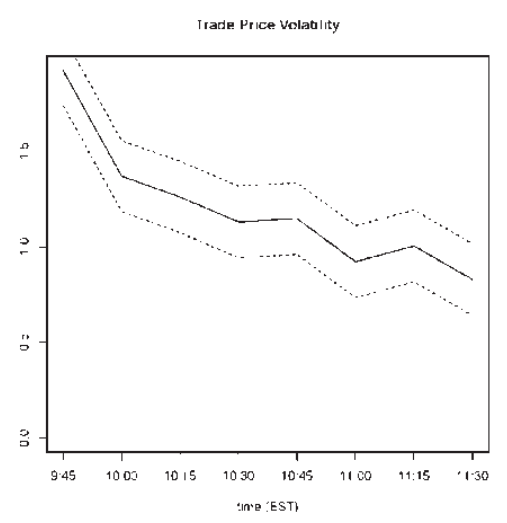

A

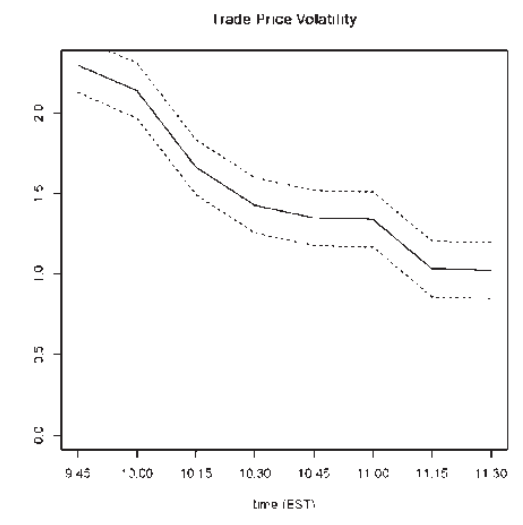

$\mathrm{D}$

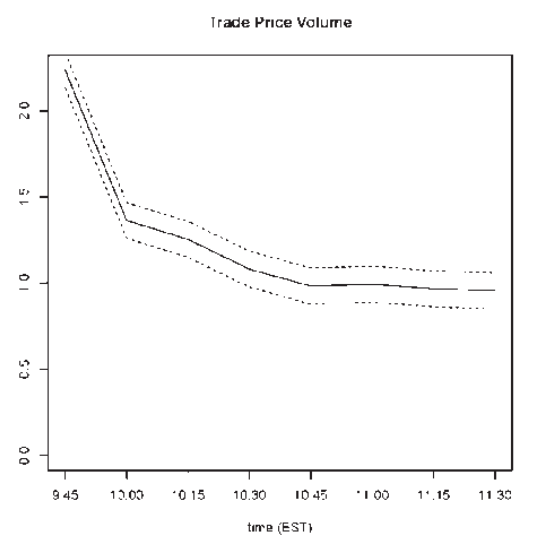

B

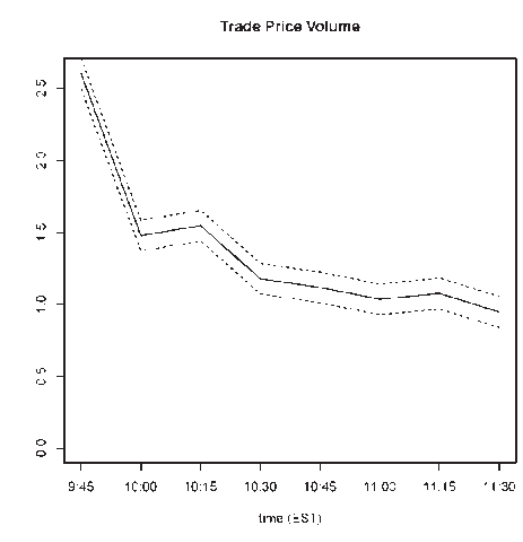

$\mathrm{E}$

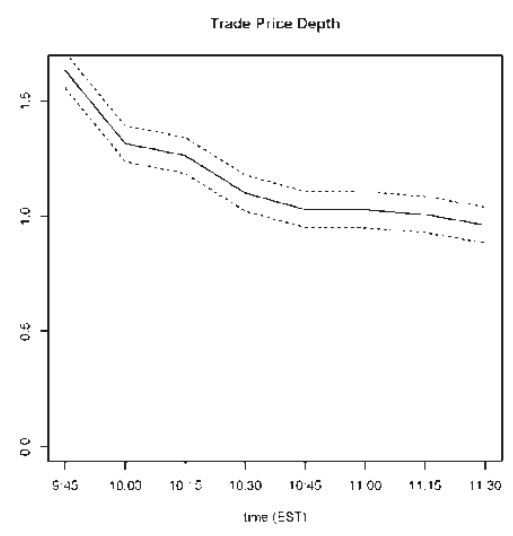

$\mathrm{C}$

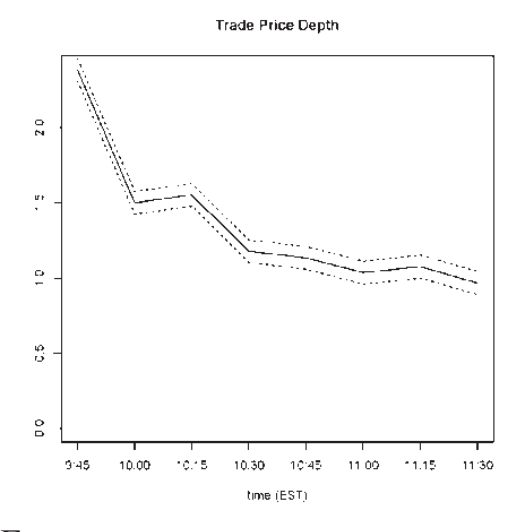

$\mathrm{F}$

The top panels, A, B, C, represent September through November 2008 while the bottom panels, D, E, F, represent June through November 2010. These graphs illustrate the results of the regression for the intraday patterns. The dotted line represents the $99 \%$ confidence interval. 


\section{FIGURE 8 \\ INTRADAY PATTERNS FOR ALL DUAL-LISTED LONDON ISHARES ETFS IN THE OVERLAPPING PERIOD FOR 2008 AND 2010}

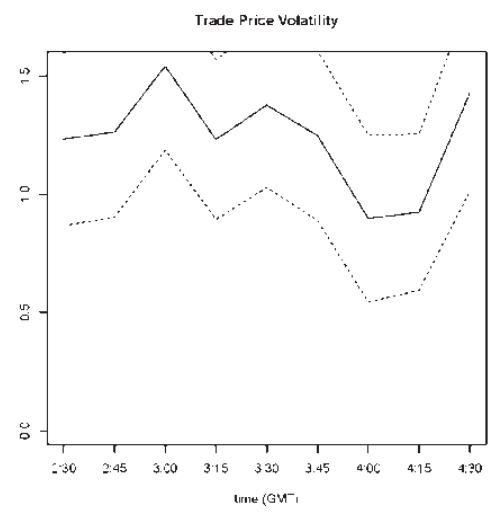

A

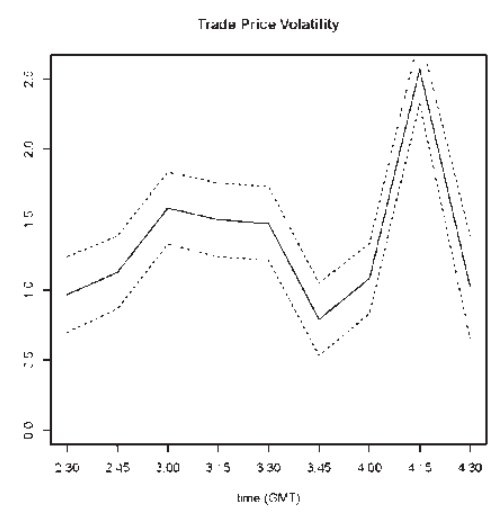

$\mathrm{D}$

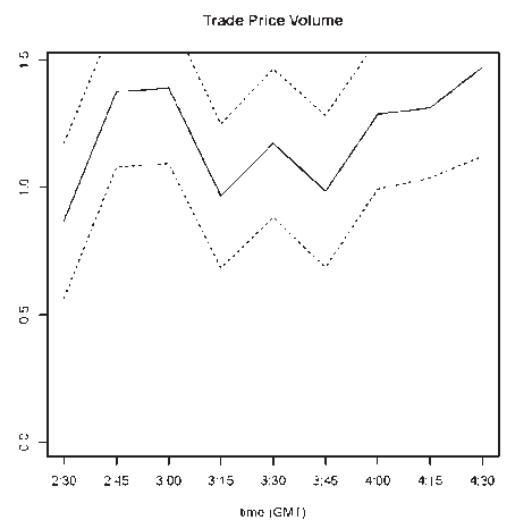

B

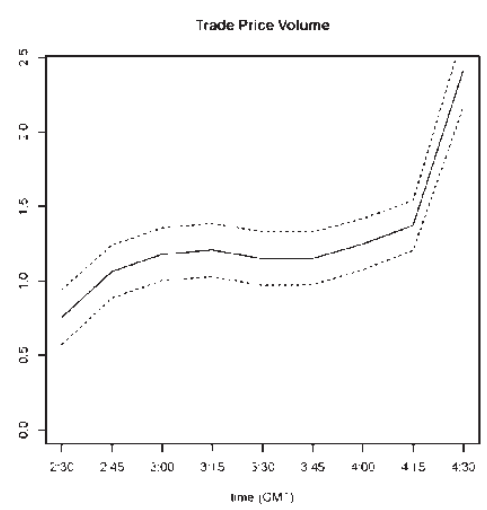

$\mathrm{E}$

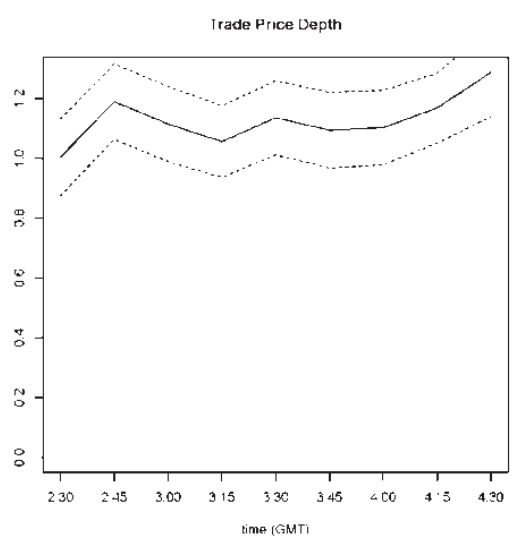

$\mathrm{C}$

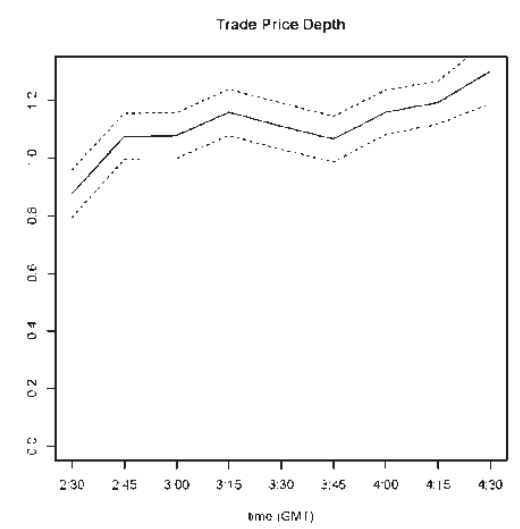

$\mathrm{F}$

The top panels, A, B, C, represent September through November 2008 while the bottom panels, D, E, F, represent June through November 2010. These graphs illustrate the results of the regression for the intraday patterns. The dotted line represents the $99 \%$ confidence interval.

It would seem that the US market and the UK market are more integrated or less sensitive to one another as compared to, for instance, the Amsterdam market (Hupperets \& Menkveld, 2002). Table 3 shows the intraday time effects. Price discovery does not appear to be as distinctive or as easily placed when looking at the US and the UK market together because as there are no distinctions to ascribe to price movements when particular events occur. However, the hypothesis that the US and the UK markets are integrated on a whole-day basis can be rejected as the intraday patterns point otherwise. In order to delve deeper into integration, the overlapping period is considered for market integration. Table 4 shows the auto-correlations and cross-correlations of dual listed iShares ETFs for the two-hour overlapping trading period between New York and London for the periods September through November 2008 and June through November 2010. The vector error correction model used by Hasbrouck (1995) is used to further detail the relationship between these two markets. First, the price series for the US and the UK are tested for co-integration. The augmented Dickey-Fuller test is conducted, and this shows that both price series are co-integrated of order one and the first difference is stationary in the overlapping period at a 99\% confidence level. This finding implies that both markets are integrated for each stock. 
TABLE 3

INTRADAY TIME EFFECTS FROM REGRESSION

\begin{tabular}{|c|c|c|c|c|c|c|c|}
\hline \multicolumn{8}{|c|}{ Panel A: Dual-listed ETFs for the whole day (2008) } \\
\hline \multirow[b]{2}{*}{ Time } & \multicolumn{4}{|c|}{ New York } & \multicolumn{3}{|l|}{ London } \\
\hline & Volatility & Volume & Depth & Time & Volatility & Volume & Depth \\
\hline $9: 30-9: 45$ & $1.92(31.32)$ & $2.23(65.88)$ & $1.63(63.00)$ & $8: 30-8: 45$ & $0.89(5.61)$ & $0.83(5.86)$ & $0.87(15.94$ \\
\hline $9: 45-10: 00$ & $1.37(21.99)$ & $1.36(39.58)$ & $1.31(49.97)$ & $8: 45-9: 00$ & $1.30(8.13)$ & $0.69(4.83)$ & $0.83(15.01)$ \\
\hline $\begin{array}{r}10: 00- \\
10: 15\end{array}$ & $1.26(20.07)$ & $1.25(36.09)$ & $1.26(47.61)$ & $9: 00-9: 15$ & $0.78(5.26)$ & $0.89(6.72)$ & $0.93(18.31)$ \\
\hline $\begin{array}{c}10: 15- \\
10: 30\end{array}$ & $1.13(17.92)$ & $1.08(31.01)$ & $1.10(41.32)$ & $9: 15-9: 30$ & $1.01(7.09)$ & $0.77(6.04)$ & $0.87(17.65)$ \\
\hline $\begin{array}{r}10: 30- \\
10: 45 \\
\end{array}$ & $1.15(18.18)$ & $0.98(28.16)$ & $1.03(38.63$ & $9: 30-9: 45$ & $0.70(4.69)$ & $0.83(6.19)$ & $0.90(17.48)$ \\
\hline $\begin{array}{r}10: 45- \\
11: 00\end{array}$ & $0.92(14.56)$ & $0.99(28.36)$ & $1.03(38.43)$ & 9:45-10:00 & $0.69(4.67)$ & $1.32(9.92)$ & $0.95(18.75)$ \\
\hline $\begin{array}{r}11: 00- \\
11: 15\end{array}$ & $1.00(15.89)$ & $0.97(27.70)$ & $1.01(37.73)$ & $\begin{array}{r}10: 00- \\
10: 15\end{array}$ & $0.47(3.34)$ & $0.85(6.68)$ & $1.03(20.99)$ \\
\hline $\begin{array}{r}11: 15- \\
11: 30\end{array}$ & $0.83(13.11)$ & $0.95(27.32)$ & $0.96(36.03)$ & $\begin{array}{r}10: 15- \\
10: 30\end{array}$ & $0.67(4.72)$ & $0.82(6.44)$ & $0.92(18.80)$ \\
\hline $\begin{array}{r}11: 30- \\
11: 45\end{array}$ & $1.06(16.79)$ & $0.84(24.08)$ & $0.87(32.60)$ & $\begin{array}{r}10: 30- \\
10: 45\end{array}$ & $0.54(3.88)$ & $0.92(7.45)$ & $0.98(20.48)$ \\
\hline $\begin{array}{c}11: 45- \\
12: 00\end{array}$ & $0.63(09.89)$ & $0.80(22.94)$ & $0.84(31.41)$ & $\begin{array}{r}10: 45- \\
11: 00\end{array}$ & $0.58(4.06)$ & $0.78(6.07)$ & $0.98(19.72)$ \\
\hline $\begin{array}{r}12: 00- \\
12: 15\end{array}$ & $0.71(11.19)$ & $0.73(20.80)$ & $0.76(28.33)$ & $\begin{array}{r}11: 00- \\
11: 15\end{array}$ & $1.35(9.14)$ & $0.73(5.54)$ & $0.95(18.62)$ \\
\hline $\begin{array}{r}12: 15- \\
12: 30\end{array}$ & $0.79(12.58)$ & $0.71(20.25)$ & $0.74(27.59)$ & $\begin{array}{r}11: 15- \\
11: 30\end{array}$ & $1.19(8.12)$ & $1.01(7.65)$ & $1.09(21.62)$ \\
\hline $\begin{array}{r}12: 30- \\
12: 45\end{array}$ & $0.60(09.51)$ & $0.65(18.60)$ & $0.72(26.76)$ & $\begin{array}{r}11: 30- \\
11: 45\end{array}$ & $1.01(6.89)$ & $1.0(7.49)$ & $0.94(18.42)$ \\
\hline $12: 45-1: 00$ & $0.73(11.54)$ & $0.68(19.42)$ & $0.73(27.18)$ & $\begin{array}{r}11: 45- \\
12: 00\end{array}$ & $0.77(5.11)$ & $1.01(7.41)$ & $0.97(18.63)$ \\
\hline $1: 00-1: 15$ & $0.69(10.79)$ & $0.69(19.59)$ & $0.71(26.20)$ & $\begin{array}{r}12: 00- \\
12: 15\end{array}$ & $0.53(3.48)$ & $0.99(7.19)$ & $0.97(18.46)$ \\
\hline $1: 15-1: 30$ & $0.93(14.58)$ & $0.69(19.52)$ & $0.76(28.05)$ & $\begin{array}{r}12: 15- \\
12: 30\end{array}$ & $0.75(4.67)$ & $0.81(5.59)$ & $0.98(17.70)$ \\
\hline $1: 30-1: 45$ & $0.73(11.49)$ & $0.76(21.52)$ & $0.81(30.07)$ & $\begin{array}{r}12: 30- \\
12: 45\end{array}$ & $0.80(5.03)$ & $0.96(6.66)$ & $0.90(16.36)$ \\
\hline $1: 45-2: 00$ & $0.70(10.99)$ & $0.73(20.70)$ & $0.78(28.93)$ & $12: 45-1: 00$ & $0.59(3.69)$ & $0.96(6.61)$ & $0.90(16.25)$ \\
\hline $2: 00-2: 15$ & $0.84(13.18)$ & $0.78(22.17)$ & $0.86(31.85)$ & $1: 00-1: 15$ & $0.92(5.82)$ & $0.64(4.53$ & $0.90(16.51)$ \\
\hline $2: 15-2: 30$ & $0.84(13.27)$ & $0.82(23.56)$ & $0.89(33.78)$ & $1: 15-1: 30$ & $1.37(8.40)$ & $0.95(6.50)$ & $0.92(16.42)$ \\
\hline $2: 30-2: 45$ & $0.79(12.56)$ & $0.80(22.84)$ & $0.88(32.79)$ & $1: 30-1: 45$ & $1.28(7.88)$ & $1.21(8.47)$ & $0.92(16.64)$ \\
\hline $2: 45-3: 00$ & $0.90(14.26)$ & $0.86(24.75)$ & $0.93(34.72)$ & $1: 45-2: 00$ & $1.13(7.19)$ & $0.96(6.96)$ & $0.89(16.69)$ \\
\hline $3: 00-3: 15$ & $1.18(08.85)$ & $0.95(27.54)$ & $1.02(38.70)$ & $2: 00-2: 15$ & $0.92(6.47)$ & $0.85(6.65)$ & $0.92(18.78)$ \\
\hline $3: 15-3: 30$ & $1.07(17.03)$ & $1.08(31.11)$ & $1.13(42.81)$ & $2 \cdot 15-2 \cdot 30$ & $123(9.51)$ & $0.87(7.45)$ & $10(2239)$ \\
\hline $3: 30-3: 45$ & $1.57(25.45)$ & $1.31(38.22)$ & $1.31(50.22)$ & $2: 30-2: 45$ & $1.26(9.89)$ & $1.38(12.06)$ & $1.19(27.16)$ \\
\hline $3: 45-4: 00$ & $1.66(23.22)$ & $2.44(61.79)$ & $2.06(68.26)$ & $2: 45-3: 00$ & $1.54(12.23)$ & $1.39(12.21)$ & $1.11(25.52)$ \\
\hline & & & & $3: 00-3 ; 15$ & $1.23(10.28)$ & $0.97(8.90)$ & $1.06(25.36)$ \\
\hline & & & & $3: 15-3: 30$ & $1.38(11.16)$ & $1.17(10.49)$ & $1.14(26.42)$ \\
\hline & & & & $3: 30-3: 45$ & $1.25(9.79)$ & $0.98(8.58)$ & $1.09(24.86)$ \\
\hline & & & & $3: 45-4: 00$ & $0.89(7.17)$ & $1.29(11.4)$ & $1.10(25.48)$ \\
\hline & & & & $4: 00-4: 15$ & $0.92(7.88)$ & $1.31(12.41)$ & $1.16(28.78)$ \\
\hline & & & & $4: 15-4: 30$ & $1.43(9.69)$ & $1.47(10.98)$ & $1.29(25.02)$ \\
\hline F-Statistic & 275.7 & 953.7 & 1514 & F-Statistic & 53.51 & 63.75 & 417.7 \\
\hline $\begin{array}{l}\text { Adjusted } \\
\mathrm{R}^{2}\end{array}$ & 0.3223 & 0.6223 & 0.7235 & $\begin{array}{r}\text { Adjusted } \\
\mathrm{R}^{2}\end{array}$ & 0.2487 & 0.2769 & 0.72 \\
\hline Std. Error & 1.523 & 0.8431 & 0.6438 & Std. Error & 1.797 & 1.642 & 0.63 \\
\hline
\end{tabular}


The estimates from the regression for the time effect are provided. The parentheses contain the tstatistic that tests whether the estimate is significantly different from zero. The model is computed similar to Werner and Kleidon (1996) where $\frac{Y_{f, d, t}}{\delta_{f, t}}=\sum_{i=t_{0}}^{T} J^{i}(t) \alpha_{i}+\left(\sum_{i=t_{0}}^{T}\left(J^{i}(t) \sigma_{i}\right)\right) \varepsilon_{f, d, t}$

$\mathrm{Y}$ is volume, volatility or spread, and $\mathrm{f}$ is the ETF, $\mathrm{d}$ is the day, and $\mathrm{t}$ is the time interval. $\delta$ represents the fund specific, day specific mean. The dummy vector of $\mathrm{J}^{\mathrm{i}}(\mathrm{t})$ is a $\{0,1\}$ vector with value of one only when $\mathrm{i}=\mathrm{t}$. The error term, $\varepsilon_{\mathrm{f}, \mathrm{d}, \mathrm{t}}$ is iid with a mean of zero and variance of one. The $\sigma$ vector represents the intraday variance, and can be heteroskedastic.

\begin{tabular}{|c|c|c|c|c|c|c|c|}
\hline \multicolumn{8}{|c|}{ Panel B: Dual-listed ETFs for the whole day (2010) } \\
\hline Time & Volatility & Volume & Depth & Time & Volatility & Volume & Depth \\
\hline $9: 30-9: 45$ & $2.29(47.07)$ & $2.61(75.99)$ & $2.39(97.73)$ & $8: 30-8: 45$ & $1.06(11.57)$ & $0.83(10.67)$ & $0.87(25.02)$ \\
\hline $9: 45-10: 00$ & $2.14(43.20)$ & $1.48(42.44)$ & $1.50(60.58)$ & $8: 45-9: 00$ & $1.03(11.10)$ & $0.72(9.04)$ & $0.82(23.45)$ \\
\hline $\begin{array}{r}10: 00- \\
10: 15\end{array}$ & $1.66(33.70)$ & $1.55(44.58)$ & $1.55(62.90)$ & $9: 00-9: 15$ & $1.17(13.49)$ & $0.75(10.14)$ & $0.89(27.32)$ \\
\hline $\begin{array}{r}10: 15- \\
10: 30\end{array}$ & $1.43(28.83)$ & $1.18(33.84)$ & $1.18(47.56)$ & $9: 15-9: 30$ & $0.87(10.42)$ & $0.97(13.64)$ & $1.00(31.95)$ \\
\hline $\begin{array}{r}10: 30- \\
10: 45\end{array}$ & $1.35(27.32)$ & $1.12(32.17)$ & $1.13(45.91)$ & $9: 30-9: 45$ & $0.66(8.07)$ & $0.99(14.31)$ & $1.07(34.95)$ \\
\hline $10: 45-$ & $1.34(27.05)$ & $1.03(29.72)$ & $1.04(41.79)$ & $9: 45-10: 00$ & $0.68(8.28)$ & $0.88(12.45)$ & $0.98(31.48)$ \\
\hline $\begin{array}{r}11: 00 \\
11: 00- \\
11: 15\end{array}$ & $1.03(20.63)$ & $1.07(30.54)$ & $1.08(42.95)$ & $\begin{array}{l}10: 00- \\
10: 15\end{array}$ & $0.80(9.51)$ & $0.93(13.01)$ & $0.94(29.62)$ \\
\hline $\begin{array}{r}11: 15- \\
11: 30\end{array}$ & $1.02(20.38)$ & $0.95(26.80)$ & $0.97(38.45)$ & $\begin{array}{l}10: 15- \\
10: 30\end{array}$ & $0.64(7.72)$ & $0.87(12.23)$ & $1.01(32.05)$ \\
\hline $\begin{array}{r}11: 30- \\
11: 45\end{array}$ & $0.83(16.47)$ & $0.88(24.71)$ & $0.86(33.83)$ & $\begin{array}{l}10: 30- \\
10: 45\end{array}$ & $0.61(7.37)$ & $0.93(13.13)$ & $1.05(33.48)$ \\
\hline $\begin{array}{r}11: 45- \\
12: 00\end{array}$ & $0.79(15.51)$ & $0.79(22.26)$ & $0.77(30.38)$ & $\begin{array}{l}10: 45- \\
11: 00\end{array}$ & $0.57(6.87)$ & $1.12(15.62)$ & $1.06(33.41)$ \\
\hline $\begin{array}{r}12: 00- \\
12: 15\end{array}$ & $0.64(12.64)$ & $0.72(20.24)$ & $0.73(28.72)$ & $\begin{array}{l}11: 00- \\
11: 15\end{array}$ & $0.54(6.48)$ & $0.86(12.14)$ & $1.00(32.00)$ \\
\hline $\begin{array}{r}12: 15- \\
12: 30\end{array}$ & $0.62(12.09)$ & $0.57(16.01)$ & $0.61(23.97)$ & $\begin{array}{l}11: 15- \\
11: 30\end{array}$ & $0.54(6.34)$ & $0.88(12.20)$ & $0.95(29.89)$ \\
\hline $\begin{array}{r}12: 30- \\
12: 45\end{array}$ & $0.59(11.49)$ & $0.61(16.97)$ & $0.63(24.73)$ & $\begin{array}{l}11: 30- \\
11: 45\end{array}$ & $0.56(6.33)$ & $0.76(10.05)$ & $0.93(27.67)$ \\
\hline $12: 45-1: 00$ & $0.63(12.25)$ & $0.59(16.32)$ & $0.61(23.71)$ & $\begin{array}{l}11: 45- \\
12: 00\end{array}$ & $0.95(10.72)$ & 080(10.60) & $0.88(26.27)$ \\
\hline $1: 00-1: 15$ & $0.68(13.32)$ & $0.63(17.48)$ & $0.66(25.76)$ & $\begin{array}{l}12: 00- \\
12: 15\end{array}$ & $0.84(9.15)$ & $0.99(12.71)$ & $0.96(27.58)$ \\
\hline $1: 15-1: 30$ & $0.55(10.71)$ & $0.64(17.64)$ & $0.65(25.15)$ & $\begin{array}{l}12: 15- \\
12: 30\end{array}$ & $0.68(7.22)$ & $0.89(10.99)$ & $0.94(26.18)$ \\
\hline $1: 30-1: 45$ & $0.70(13.62)$ & $0.58(16.15)$ & $0.60(23.51)$ & $\begin{array}{l}12: 30- \\
12: 45\end{array}$ & $0.54(5.55)$ & $0.87(10.51)$ & $0.86(23.55)$ \\
\hline $1: 45-2: 00$ & $0.79(15.46)$ & $0.61(16.96)$ & $0.60(23.63)$ & $12: 45-1: 00$ & $0.92(9.48)$ & $0.81(9.68)$ & $0.86(23.43)$ \\
\hline $2: 00-2: 15$ & $0.80(15.80)$ & $0.78(21.83)$ & $0.75(29.62)$ & $1: 00-1: 15$ & $0.94(9.93)$ & $0.86(10.59)$ & $0.84(23.59)$ \\
\hline $2: 15-2: 30$ & $0.81(15.93)$ & $0.67(18.78)$ & $0.75(29.52)$ & $1: 15-1: 30$ & $1.22(13.37)$ & $1.00(12.97)$ & $0.91(26.45)$ \\
\hline $2: 30-2: 45$ & $0.83(16.40)$ & $0.69(19.36)$ & $0.76(29.82)$ & $1: 30-1: 45$ & $1.22(13.50)$ & $1.01(13.93)$ & $1.05(31.05)$ \\
\hline $2: 45-3: 00$ & $0.65(12.73)$ & $0.68(18.99)$ & $0.71(28.06)$ & $1: 45-2: 00$ & $0.75(8.50)$ & $0.79(10.54)$ & $0.91(27.25)$ \\
\hline $3: 00-3: 15$ & $0.80(15.81)$ & $0.71(20.12)$ & $0.75(29.68)$ & $2: 00-2: 15$ & $0.68(7.99)$ & $0.84(11.55)$ & $0.87(26.93)$ \\
\hline $3: 15-3: 30$ & $0.98(19.56)$ & $0.93(26.36)$ & $0.95(37.76)$ & $2: 15-2: 30$ & $0.97(12.47)$ & $0.76(11.46)$ & $0.88(30.01)$ \\
\hline $3: 30-3: 45$ & $0.93(18.94)$ & $1.12(32.32)$ & $1.19(48.18)$ & $2: 30-2: 45$ & $1.12(15.02)$ & $1.06(16.70)$ & $1.07(38.17)$ \\
\hline $3: 45-4: 00$ & $0.84(17.53)$ & $2.39(71.4)$ & $2.20(92.13)$ & 2:45-3:00 & $1.58(21.35)$ & $1.18(18.70)$ & $1.08(38.62)$ \\
\hline & & & & $3: 00-3 ; 15$ & $1.50(19.77)$ & 1.21(18.89) & $1.16(40.98)$ \\
\hline & & & & 3:15-3:30 & $1.47(19.48)$ & $1.15(17.90)$ & $1.11(39.08)$ \\
\hline & & & & $3: 30-3: 45$ & $0.79(10.6)$ & $1.15(8.21)$ & $1.07(38.12)$ \\
\hline & & & & $3: 45-4: 00$ & $1.08(15.03)$ & $1.25(20.33)$ & $1.16(42.67)$ \\
\hline & & & & $4: 00-4: 15$ & $2.57(36.46)$ & $1.37(23.01)$ & $1.19(45.16)$ \\
\hline & & & & $4: 15-4: 30$ & $1.02(9.66)$ & $2.42(27.07)$ & $1.30(32.95)$ \\
\hline F-Statistic & 477.6 & 1022 & 1931 & F-Statistic & 168.50 & 207.60 & 1004 \\
\hline $\begin{array}{l}\text { Adjusted } \\
\mathrm{R}^{2}\end{array}$ & 0.3099 & 0.4903 & 0.6452 & $\begin{array}{l}\text { Adjusted } \\
\mathrm{R}^{2}\end{array}$ & 0.2365 & 0.2707 & 0.6431 \\
\hline Std. Error & 1.637 & 1.15 & 0.819 & Std. Error & 1.962 & 1.693 & 0.7491 \\
\hline
\end{tabular}




\begin{tabular}{|c|c|c|c|c|c|c|c|}
\hline \multicolumn{5}{|c|}{$\begin{array}{l}\text { Panel C: Dual-listed ETFs for the overlapping period (2008) } \\
\text { New York }\end{array}$} & \multicolumn{3}{|l|}{ London } \\
\hline Time & Volatility & Volume & Depth & Time & Volatility & Volume & Depth \\
\hline $9: 30-9: 45$ & $1.92(27.14)$ & $2.23(56.77)$ & $1.63(55.31)$ & $2: 30-2: 45$ & $1.26(9.04)$ & $1.38(11.94)$ & $1.19(24.34)$ \\
\hline $\begin{array}{c}9: 45- \\
10: 00\end{array}$ & $1.37(19.06)$ & $1.36(34.11)$ & $1.31(43.87)$ & $2: 45-3: 00$ & $1.54(11.18)$ & $1.39(11.94)$ & $1.11(22.87)$ \\
\hline $\begin{array}{r}10: 00- \\
10: 15\end{array}$ & $1.26(17.39)$ & $1.25(31.10)$ & $1.26(41.79)$ & $3: 00-3 ; 15$ & $1.23(9.40)$ & $0.97(8.82)$ & $1.06(22.73)$ \\
\hline $\begin{array}{r}10: 15- \\
10: 30\end{array}$ & $1.13(15.53)$ & $1.08(26.72)$ & $1.10(36.28)$ & $3: 15-3: 30$ & $1.38(10.20)$ & $1.17(10.38)$ & $1.14(23.68)$ \\
\hline $\begin{array}{r}10: 30- \\
10: 45\end{array}$ & $1.15(15.76)$ & $0.98(24.27)$ & $1.03(33.91)$ & $3: 30-3: 45$ & $1.25(8.96)$ & $0.98(8.50)$ & $1.09(22.29)$ \\
\hline $\begin{array}{r}10: 45- \\
11: 00\end{array}$ & $0.92(12.62)$ & $0.99(24.44)$ & $1.03(33.74)$ & $3: 45-4: 00$ & $0.90(6.55)$ & $1.29(11.3)$ & $1.10(22.84)$ \\
\hline $\begin{array}{r}11: 00- \\
11: 15\end{array}$ & $1.00(13.77)$ & $0.97(23.87)$ & $1.01(33.13)$ & $4: 00-4: 15$ & $0.92(7.21)$ & $1.31(12.29)$ & $1.17(25.8)$ \\
\hline $\begin{array}{r}11: 15- \\
11: 30\end{array}$ & $0.83(11.36)$ & $0.95(23.54)$ & $0.96(31.63)$ & $4: 15-4: 30$ & $1.43(8.86)$ & $1.48(10.87)$ & $1.29(22.43)$ \\
\hline F-Statistic & 296.2 & 1047 & 1554 & F-Statistic & 80.9 & 110.8 & 531.4 \\
\hline $\begin{array}{l}\text { Adjusted } \\
\mathrm{R}^{2}\end{array}$ & 0.3338 & 0.6395 & 0.7247 & $\begin{array}{r}\text { Adjusted } \\
\mathrm{R}^{2}\end{array}$ & 0.2833 & 0.35 & 0.7191 \\
\hline Std. Error & 1.757 & 0.9873 & 0.7333 & Std. Error & 1.97 & 1.66 & 0.7028 \\
\hline
\end{tabular}

Panel D: Dual-listed ETFs for the overlapping period (2010)

\begin{tabular}{|c|c|c|c|c|c|c|c|}
\hline \multirow[b]{2}{*}{ Time } & \multicolumn{4}{|l|}{ New York } & \multicolumn{3}{|l|}{ London } \\
\hline & Volatility & Volume & Depth & Time & Volatility & Volume & Depth \\
\hline $9: 30-9: 45$ & $2.30(35.04)$ & $2.61(63.95)$ & $2.39(82.30$ & $2: 30-2: 45$ & $1.12(11.19)$ & $1.06(15.38)$ & $1.07(34.70)$ \\
\hline $\begin{array}{c}9: 45- \\
10: 00\end{array}$ & $2.14(32.16)$ & $1.48(35.71)$ & $1.50(51.01$ & $2: 45-3: 00$ & $1.58(15.89)$ & $1.18(17.23)$ & $1.08(35.1)$ \\
\hline $\begin{array}{c}10: 00- \\
10: 15\end{array}$ & $1.66(25.09)$ & $1.55(37.51)$ & $1.55(52.97)$ & $3: 00-3 ; 15$ & $1.50(14.72)$ & $1.21(17.41)$ & $1.16(37.24)$ \\
\hline $\begin{array}{r}10: 15- \\
10: 30\end{array}$ & $1.43(21.46)$ & $1.18(28.48)$ & $1.18(40.05)$ & $3: 15-3: 30$ & $1.47(14.50)$ & $1.15(16.49)$ & $1.11(35.52)$ \\
\hline $\begin{array}{c}10: 30- \\
10: 45\end{array}$ & $1.35(20.34)$ & $1.12(27.07)$ & $1.13(28.66)$ & $3: 30-3: 45$ & $0.79(7.89)$ & $1.15(16.78)$ & $1.07(34.65)$ \\
\hline $\begin{array}{r}10: 45- \\
11: 00\end{array}$ & $1.34(20.14)$ & $1.03(25.01)$ & $1.04(35.19)$ & $3: 45-4: 00$ & $1.08(11.19)$ & $1.25(18.73)$ & $1.16(38.79)$ \\
\hline $\begin{array}{r}11: 00- \\
11: 15\end{array}$ & $1.03(15.36)$ & $1.07(25.70)$ & $1.08(36.17)$ & $4: 00-4: 15$ & $2.57(27.14)$ & $1.37(21.20)$ & $1.19(41.05)$ \\
\hline $\begin{array}{r}11: 15- \\
11: 30\end{array}$ & $1.02(15.17)$ & $0.95(22.55)$ & $0.97(32.38)$ & $4: 15-4: 30$ & $1.02(7.19)$ & $2.42(24.94)$ & $1.30(29.95)$ \\
\hline F-Statistic & 579.6 & 1264 & 2359 & F-Statistic & 207.3 & 324.8 & 1235 \\
\hline $\begin{array}{l}\text { Adjusted } \\
\mathrm{R}^{2}\end{array}$ & 0.3462 & 0.5362 & 0.6834 & $\begin{array}{r}\text { Adjusted } \\
\mathrm{R}^{2}\end{array}$ & 0.2385 & 0.3233 & 0.6445 \\
\hline Std. Error & 2.2 & 1.367 & 0.9726 & Std. Error & 2.635 & 1.838 & 0.8242 \\
\hline
\end{tabular}


TABLE 4

CORRELATIONS OF TRADE PRICE RETURNS DURING THE OVERLAPPING PERIOD

\begin{tabular}{lrrrr}
\hline & \multicolumn{2}{c}{2008} & \multicolumn{2}{c}{2010} \\
\cline { 2 - 5 } & $\begin{array}{r}\text { New } \\
\text { York }\end{array}$ & London & New York & London \\
\hline Auto-correlations & & & & \\
15 minutes & 0.153 & -0.026 & 0.183 & 0.001 \\
30 minutes & -0.059 & 0.021 & 0.020 & -0.004 \\
Cross-correlations & & & & \\
New York lagged & & & 0.023 & \\
15 minutes & -0.021 & & -0.009 & \\
30 minutes & 0.008 & & & 0.004 \\
London lagged & & & & -0.010 \\
15 minutes & & -0.008 & & \\
30 minutes & & 0.011 & & \\
\hline
\end{tabular}

This table contains the auto-correlations and cross-correlations of dual listed iShares ETFs for the two-hour overlapping trading period between New York and London for the periods September through November 2008 and June through November 2010.

Table 5 presents the results of the vector error correction model. The error term and the adjusted $\mathrm{R}^{2}$ for the London market are larger than the error term and the adjusted $\mathrm{R}^{2}$ for the New York market. This observation suggests that the London market is more dependent on historical information and thus is more impacted by news, such as macro-economic information, than the New York market. The magnitude of the $\mathrm{R}^{2}$ is larger in 2010 than in 2008 for London while remaining relatively constant for the New York market. This observation could be an indication of the recovery from the whirlwind of financial activity as a result of the worldwide panic in 2008 back to the normal level of activity at the London market in 2010. Hence, London is more likely to be impacted by historical events in the US than New York is affected by events in the UK. In 2008, the error correction term is statistically significant at the $10 \%$ level for both New York and London, but in 2010, the statistical significance disappears. The returns are significantly positive for London while there are significantly negative returns for New York in 2008. Again, this observation seems to be a result of the financial meltdown in 2008. In 2010, there appears to be a recovery where market information is assimilated within two lags or 30 minutes as this finding is statistically significant in both London and New York. The vector error correction results imply that there was a rapid adjustment to prices in 2008, which would explain why there was wide spread contagion between these two markets. However, in 2010, with the markets stabilized again, the vector error correction estimate is no longer significant, and price discovery is not relegated to any one market but moves across both markets accordingly. 
TABLE 5

VECTOR ERROR CORRECTION RESULTS

\begin{tabular}{|c|c|c|c|c|c|c|c|c|}
\hline \multicolumn{9}{|c|}{ Panel A: 2008} \\
\hline & \multicolumn{3}{|c|}{ New York lags } & \multicolumn{5}{|l|}{$\begin{array}{l}\text { London } \\
\text { lags }\end{array}$} \\
\hline & $\mathrm{P}_{\mathrm{NY}}-\mathrm{P}_{\mathrm{LN}}$ & -15 & -30 & -15 & -30 & $\mathrm{n}$ & $\operatorname{Adj} R^{2}$ & Std Error \\
\hline New York & $\begin{array}{r}-0.0001 \\
(-1.71)\end{array}$ & $\begin{array}{r}-0.2254 \\
(-12.908)\end{array}$ & $\begin{array}{r}-0.2469 \\
(-20.328)\end{array}$ & $\begin{array}{c}0.0011 \\
(0.224)\end{array}$ & $\begin{array}{c}0.0023 \\
(0.436)\end{array}$ & 3281 & 0.1198 & 0.0044 \\
\hline London & $\begin{array}{r}0.0005 \\
(1.845)\end{array}$ & $\begin{array}{r}0.0846 \\
(1.35) \\
\end{array}$ & $\begin{array}{r}0.0501 \\
(1.149) \\
\end{array}$ & $\begin{array}{r}-0.6296 \\
(-36.382) \\
\end{array}$ & $\begin{array}{r}-0.4974 \\
(-26.843) \\
\end{array}$ & 3281 & 0.2981 & 0.0158 \\
\hline
\end{tabular}

Panel B: 2010

\begin{tabular}{lrrrrrrrr}
\multicolumn{1}{l}{$\begin{array}{l}\text { New York } \\
\text { lags }\end{array}$} & \multicolumn{7}{c}{$\begin{array}{l}\text { London } \\
\text { lags }\end{array}$} \\
\cline { 2 - 9 } & \multicolumn{1}{c}{$\mathrm{P}_{\mathrm{NY}-\mathrm{P}_{\mathrm{LN}}}$} & -15 & -30 & -15 & -30 & $\mathrm{n}$ & Adj R $^{2}$ & Std Error \\
\hline New York & 0.000009 & -0.2483 & -0.2099 & 0.0002 & 0.0004 & 11363 & 0.11 & 0.0010 \\
\multirow{2}{*}{ London } & $(0.977)$ & $(-26.461)$ & $(-33.879)$ & $(0.618)$ & $(0.541)$ & & & \\
& 0.000078 & 0.1556 & 0.2294 & -1.64 & -1.96 & 11363 & 0.77 & 0.0217 \\
& $(0.386)$ & $(0.745)$ & $(1.664)$ & $(-184.78)$ & $(-127.41)$ & & & \\
\hline
\end{tabular}

The results from the Vector Error Correction Model are presented here. The t-statistic is shown in parentheses. The model is computed as:

$r_{t}^{L}=\Delta \log \left(P_{t}^{L}\right)$
$r_{t}^{N}=\Delta \log \left(P_{t}^{N}\right)$
$r_{t}^{L}=\alpha^{L}\left(\log \left(P_{t-1}^{L}\right)-\log \left(P_{t-1}^{N}\right)\right)+\sum_{i=1}^{4} \gamma_{i}^{L, L} r_{t-i}^{L}+\sum_{i=1}^{4} \gamma_{i}^{L, N} r_{t-i}^{N}+\varepsilon_{t}^{A}$
$r_{t}^{N}=\alpha^{N}\left(\log \left(P_{t-1}^{L}\right)-\log \left(P_{t-1}^{N}\right)\right)+\sum_{i=1}^{4} \gamma_{i}^{N, L} r_{t-i}^{L}+\sum_{i=1}^{4} \gamma_{i}^{N, N} r_{t-i}^{N}+\varepsilon_{t}^{N}$

\section{CONCLUSION}

Microstructure research has shown the existence of a U-shape in stocks traded on the US market. However, very few research has looked at the intraday shape of reduced risk basket securities like ETFs. Here, we show that although ETFs provide the benefit of reduced risk in every share, there still exists the intraday U-shape pattern for ETFs that are traded in New York similar to that of stocks for trade price volatility, volume, and depth. Focusing on the iShares group of ETFs to analyze integration between markets is fruitful. The New York iShares ETFs exhibit a similar U-shape pattern for New York ETFs while the London ETFs have a shape that is consistent with a double humped pattern.

The US and the UK markets are not integrated across the whole day but in the overlapping period, there is evidence of integration here with limited price discovery outside of the financial meltdown of 2008. 


\section{REFERENCES}

Abhyankar, A., Ghosh, D., Levin, E., \& Limmack, R. J. (1997, April). Bid-Ask Spreads, Trading Volume and Volatility: Intra-Day Evidence from the London Stock Exchange. Journal of Business Finance \& Accounting, 24(3 \& 4), 343-362.

Cai, C. X., Hudson, R., \& Keasey, K. (2004, June/July). Intra Day Bid-Ask Spreads, Trading Volume and Volatility: Recent Empirical Evidence from the London Stock Exchange. Journal of Business Finance \& Accounting, 31(5 \& 6), 647-676.

Fama, E. F. (1970). Efficient Capital Markets: A Review of Theory and Empirical Work. The Journal of Finance, 25(2), 383-417.

Froot, K. A., \& Dabora, E. M. (1999). How Are Stock Prices Affected by the Location of Trade? Journal of Financial Economics, 53, 189-216.

Goodhart, C. A., \& O'Hara, M. (1997). High Frequency Data in Financial Markets: Issues and Applications. Journal of Empirical Finance, 4, 73-114.

Hupperets, C. J., \& Menkveld, A. J. (2002). Intraday Analysis of Market Integration: Dutch Blue Chips Traded in Amsterdam and New York. Journal of Financial Markets, 5, 57-82.

Jain, P. C., \& Joh, G.-H. (1988). The Dependence between Hourly prices and Trading Volume. The Journal of Financial and Quantitative Analysis, 23(3), 269-283.

Lin, W-L., Engle, R. F., \& Ito, T. (1994). Do Bulls and Bears Move across Borders? International Transmission of Stock Returns and Volatility. The Review of Financial Studies, 7(3), 507-538.

McInnish, T. H., \& Wood, R. A. (1992). An Analysis of Intraday Patterns in Bid/Ask Spreads for NYSE Stocks. The Journal of Finance, 47(2), 753-764.

Werner, I. M., \& Kleidon, A. W. (1996). U.K. and U.S. Trading of British Cross-Listed Stocks: An Intraday Analysis of Market Integration. The Review of Financial Studies, 9(2), 619-664. 